\title{
THE BILIARY EXCRETION OF VARIOUS BILE ACIDS BY PA- TIENTS WITH CHOLEDOCHOSTOMY DRAINAGE, AND THE EFFECT OF ORAL ADMINISTRATION OF DESICCATED BILE OF THE OX AND THE HOG ${ }^{1}$
}

\author{
BY CHARLES G. JOHNSTON AND J. LOGAN IRVIN
}

(From the Laboratory of Surgical Research, Wayne University College of Medicine, Detroit)

\author{
(Received for publication November 8, 1946)
}

Choledochostomy drainage of bile by means of a T-tube frequently is established following surgery of the biliary tract, and often such drainage is maintained for periods ranging from several weeks to several months. During this time only small amounts of bile, usually quite deficient in bile salts $(1,2)$, enter the intestine. Replacement by oral administration of bile is indicated. A method for large-scale preparation of desiccated bile has been reported, and ayerage analyses of desiccated gallbladder bile of the hog have been presented (3). Such preparations of desiccated bile are being used with success in replacement therapy (4) and for symptomatic treatment of patients with gastrointestinal disorders associated with biliary insufficiency (5).

Bile acids of man, the ox, and the hog consist of a steroid nucleus possessing a carboxyl group which usually is conjugated through amide linkage with glycine or taurine. In bile of man and the ox approximately 50 to 75 per cent of the total quantity of the bile acids ${ }^{2}$ is conjugated with glycine and the major portion of the remainder with taurine (6). However, this proportion is somewhat variable, and often a considerable fraction of the bile acids is in the "free" or unconjugated form (7). By contrast, the bile acids of hog bile are conjugated solely with glycine $(6,8)$. The bile acids of these 3 animals differ also in the nature of the steroid nuclei and in the relative proportions of these bile acids present in the bile. The principal bile acid (steroid nucleus) of hog bile is $\alpha$-hyodesoxycholic acid (3,6-dihydroxycholanic acid) (8). The principal bile acid in bile of man

\footnotetext{
1 Aided by a grant from Parke, Davis and Company.

2 It is customary to refer to the bile "acids" in bile although it is understood that at the $\mathrm{pH}$ of bile these acids are almost completely ionized as anions which are matched by sodium, potassium, and calcium cations.
}

and the ox is cholic acid (3,7,12-trihydroxycholanic acid), but important amounts of desoxycholic acid (3,12-dihydroxycholanic acid) and chenodesoxycholic acid (3,7-dihydroxycholanic acid) also are present $(9,10)$. Hyodesoxycholic acid has not been found in bile of man and the ox, and cholic acid is absent from the bile of the hog.

In view of the qualitative and quantitative differences in the bile acid composition of bile of various animals, it is important to have information concerning the utilization of various bile acids as a guide to adequate replacement therapy in hum.in patients with biliary insufficiency. In previous communications $(11,12)$ we have reported experiments which have demonstrated very efficient enterohepatic circulation of foreign bile acids in animals with experimental biliary fistulae. The present paper is a description of studies on the administration of desiccated bile of the hog and the ox to human patients with choledochostomy drainage.

\section{EXPERIMENTAL}

Cholic acid and total dihydroxycholanic acids ${ }^{3}$ were determined by methods which we have described previously $(12,13)$. The method for determining "cholic acid" yields the sum of free cholic acid, glycocholic, and taurocholic acids. Desoxycholic acid was determined by an adaptation of the procedure of Kaziro and Shimada (14). The reaction with benzaldehyde was conducted in $23 \mathrm{~N}$ sulfuric acid instead of the more concentrated acid specified by Kaziro and Shimada, thus minimizing interference by chenodesoxycholic acid. In order to attain greater specificity and eliminate interfering substances, the reaction was applied to the dihydroxycholanic acid fraction which was separated from cholic acid and from the monohydroxycholanic acid fraction by the pro-

3 The dihydroxycholanic acids which have been isolated $(9,21)$ from bile of man are desoxycholic acid and chenodesoxycholic acid. Hyodesoxycholic acid of hog bile also is a dihydroxycholanic acid $(8,15)$. Our method for the determination of "total dihydroxycholanic acids" (12) yields the sum of these 3 acids. 
cedure which we have described previously (12). Optical density measurements were made with a filter photometer at a mean wavelength of $620 \mathrm{~m} \mu$.

For the determination of hyodesoxycholic acid a sample of bile estimated to contain 25 to $75 \mathrm{mgm}$. of this acid was extracted and hydrolysed, and the dihydroxycholanic acid fraction was separated by the method previously described (12). The dihydroxycholanic acids, including hyodesoxycholic acids, were oxidized by chromic acid to diketocholanic acids as described previously (12), a proportionately larger amount of chromic acid being required because of the larger sample. The diketocholanic acid fraction was dissolved in glacial acetic acid, and the optical rotation (D line of sodium) was determined in a polarimeter equipped with a micro tube of 1 decimeter length requiring $1 \mathrm{ml}$. of solution. Then hydrochloric acid was added to the solution to a concentration of 0.5 per cent by volume, and the solution was boiled for 1 hour under reflux. During this process, the 3,6-diketocholanic acid (resulting from the oxidation of hyodesoxycholic acid) underwent rearrangement to 3,6-diketoallocholanic acid. The solution was evaporated to dryness in vacuo; then the residue was dissolved again in glacial acetic acid and brought to a volume equal to that used in the initial polarimetric measurement. The optical rotation of this solution was determined, and the initial quantity of hyodesoxycholic acid in the sample was calculated from the change in optical rotation which accompanied the rearrangement of 3,6-diketocholanic acid to 3,6-diketoallocholanic acid. This method is specific for hyodesoxycholic acid inasmuch as the other diketocholanic acids (resulting from the oxidation of the other dihydroxycholanic acids) do not undergo such rearrangement. Calculations were based upon determinations with standard amounts of hyodesoxycholic acid which were carried through the same procedure, the "unknown" being referred to polarimetric values which were obtained with standards of nearly the same concentration. This method utilizes principles which were described in the studies of Windaus $e t$ al upon the constitution of hyodesoxycholic acid $(8,15)$. Following the polarimetric measurements, a portion of the diketocholanic acid fraction was used for determination of the total diketocholanic acids from which the total dihydroxycholanic acids originally present in the sample could be calculated.

Total bile acids were calculated as the sum of cholic acid and the total dihydroxycholanic acids. This calculation of the "total bile acids" left unaccounted the traces of monohydroxycholanic acids and keto bile acids which have been found in bile.

Total conjugated bile acids and tauro-conjugated acids were determined essentially by the method of Schmidt and Dart (16). Glyco-conjugated acids were calculated by difference between the total conjugated and the tauro-conjugated acids.

The patients studied in this report were all treated for obstruction of the common duct. ${ }^{4}$ Patients C. D., A. M., and C. M. had institution of drainage of their common

\footnotetext{
${ }^{4}$ See Case Histories.
}

duct by means of a T-tube. Patient F. W. was in exceedingly poor shape when operated upon; the gallbladder was removed and drainage instituted by a large tube placed in the dilated cystic duct. Bile was allowed to flow unimpeded into a sterile bottle with a vent as described by Richey (17), the bottle being placed a few inches below the level of the patient. The few inches which the bile flowed by gravity through a large tube was not considered sufficient to obstruct the flow by causing collapse of the tube.

The collection of bile in these cases could not be considered as complete. However, since there was no impediment offered to the outflow of bile, it is to be presumed that very little bile found its way into the duodenum and that most of it was collected. That this assumption is valid has been corroborated by the fact that hyodesoxycholic acid, a bile acid not found in significant quantities in man, was recovered almost quantitatively through the drainage tube after administration to the patient by mouth. It was not possible to control each study, and the possibility of partial recoveries introduces the probability of error. Those errors which are due to incomplete recoveries would tend to give lower values than actually found. Accordingly, in considering the data presented on recoveries of bile acid, it must be recognized that there is a possibility that they may be somewhat low rather than high.

\section{DISCUSSION OF RESULTS}

The excretion of various bile acids in the choledochostomy drainage bile of these cases can be discussed more clearly by dividing the presentation into a section on the excretion in the absence of orally administered animal bile and a section on the excretion during administration of bile. Eleven cases were studied, but this report is confined to a discussion of 5 cases which were investigated in greatest detail and which illustrate the principal observations and conclusions which were derived from the entire series.

(1) Excretion of bile acids in the absence of orally administered animal bile: Following cholecystectomy and establishment of choledochostomy drainage of bile, a post-operative period of 10 to 20 days usually elapses before resumption of synthesis of bile acids by patients whose biliary tracts have been obstructed for a long period of time. Such delay in the resumption of the synthesis of cholic acid was noted previously by Ravdin et al (1), and a similar delay in synthesis of "bile acids" was observed in some of the more severely obstructed cases of Greene et al $(18,19)$ by application of an analytical method of somewhat questionable specificity. In the cases studied in the present in- 
vestigation all of the various bile acids were entirely or nearly lacking from the bile excreted during the first few days following the operation. However, the excretion of desoxycholic acid and the total dihydroxycholanic acid fraction (which includes desoxycholic acid) was resumed somewhat earlier than the excretion of cholic acid. By means of other analytical methods, Breusch and Johnston (20) obtained evidence for a similar effect. The more rapid appearance of the dihydroxycholanic acids was particularly striking in the case of A. M. (Table IV), but was less marked in the cases of C. D. and C. M. (Tables I and VI). In all cases in which both the total dihydroxycholanic acid fraction and desoxycholic acid, a specific member of that fraction, were determined, the quantity of total dihydroxycholanic acids exceeded the amount of desoxycholic acid. This is evidence for the presence of one or more additional members of the dihydroxycholanic acid series. Inasmuch as Wieland et al $(9,21)$ have isolated chenodesoxycholic acid, ${ }^{5}$ a dihydroxycholanic acid, from gallbladder bile collected from cadavers, it is likely that the differences between our figures for total dihydroxycholanic acids and the corresponding figures for desoxycholic acid are a measure of the amounts of chenodesoxycholic acid present. However, as mentioned below, in order to obtain values for chenodesoxycholic acid in those cases in which hog bile was administered to the patients it would be necessary also to subtract the figure for hyodesoxycholic acid since this bile acid is included in the dihydroxycholanic acid fraction. The traces of "hyodesoxycholic acid" recorded in Table IV for periods in which hog bile was not administered to this patient correspond to "blank" values obtained with the polarimetric method for the determination of this bile acid and probably do not represent the presence of true hyodesoxycholic acid in these samples.

5 Wieland isolated this bile acid from the bile of man in 1924, and he gave it the name, anthropodesoxycholic acid. Windaus in the same year announced the isolation of the identical compound from the bile of the goose and named it chenodesoxycholic acid. No general agreement regarding the name appears to have been reached, but the name proposed by Windaus seems to be favored since the prefix, cheno, was used first by Heintz and Wislicenus in connection with an imperfectly characterized acid which they isolated from bile of the goose in 1859.
Average figures for these "blanks" were used in correcting all values obtained for hyodesoxycholic acid by this method.

The biliary excretion after approximately the twentieth day following the operation probably represents an approach to normal hepatic bile, at least in a few of the cases in which there appeared to be minimal liver damage from obstruction and cholangitis. The extent of such damage is difficult to assess, but, of the cases studied in greatest detail, it would appear that C. D. (Tables I and II) most nearly attained a normal state of biliary

TABLE I

Excretion of various bile acids in the choledochostomy drainage bile of patient $C . D$., and the effect of oral administration of desiccated hog bile

\begin{tabular}{|c|c|c|c|c|c|c|c|}
\hline \multirow{2}{*}{$\begin{array}{c}\text { Days } \\
\text { post- } \\
\text { opera- } \\
\text { tive }\end{array}$} & \multirow{2}{*}{$\begin{array}{c}\text { Hyodesoxy- } \\
\text { cholic } \\
\text { acid } \\
\text { content of } \\
\text { hog bile } \\
\text { adminis- } \\
\text { tered }\end{array}$} & \multirow{2}{*}{\begin{tabular}{|c|} 
Aver- \\
age \\
volume \\
of bile \\
excreted \\
per \\
day
\end{tabular}} & \multicolumn{5}{|c|}{$\begin{array}{l}\text { Concentration of bile acids in } \\
\text { drainage bile }\end{array}$} \\
\hline & & & $\begin{array}{c}\text { Cholic } \\
\text { acid }\end{array}$ & $\begin{array}{c}\text { Desoxy- } \\
\text { cholic } \\
\text { acid }\end{array}$ & $\begin{array}{l}\text { Hyo- } \\
\text { desoxy- } \\
\text { cholic } \\
\text { acid }\end{array}$ & $\begin{array}{l}\text { Total } \\
\text { dihy- } \\
\text { droxy- } \\
\text { cho- } \\
\text { lanic } \\
\text { acid }\end{array}$ & $\begin{array}{l}\text { Total } \\
\text { bile } \\
\text { acids }\end{array}$ \\
\hline & $\begin{array}{c}\text { millimoles } \\
\text { per day }\end{array}$ & $m l$. & \multicolumn{5}{|c|}{ millimoles per liter } \\
\hline $\begin{array}{c}2 \\
3-4 \\
5-6 \\
7-8 \\
9-10 \\
11 \\
12 \\
13 \\
14 \\
15 \\
16 \\
17 \\
18 \\
19 \\
20 \\
21 \\
22 \\
23 \\
24 \\
25\end{array}$ & $\begin{array}{c}0 \\
0 \\
0 \\
0 \\
0 \\
0 \\
0 \\
0 \\
0 \\
0 \\
0 \\
0 \\
0 \\
0 \\
0 \\
0 \\
2.8 \\
2.8 \\
0 \\
0\end{array}$ & $\begin{array}{r}425 \\
370 \\
460 \\
540 \\
380 \\
510 \\
580 \\
540 \\
530 \\
610 \\
505 \\
605 \\
550 \\
560 \\
590 \\
600 \\
985 \\
1,010 \\
790 \\
685\end{array}$ & $\begin{array}{c}0 \\
0 \\
0 \\
\text { trace } \\
0.3 \\
0.6 \\
1.2 \\
2.9 \\
4.1 \\
5.8 \\
6.9 \\
8.3 \\
9.4 \\
9.8 \\
9.2 \\
10.0 \\
10.2 \\
9.7 \\
12.2 \\
14.3\end{array}$ & $\begin{array}{c}0 \\
\text { trace } \\
0.10 \\
0.15 \\
0.20 \\
0.40 \\
0.46 \\
0.70 \\
0.95 \\
1.6 \\
2.1 \\
3.0 \\
3.0 \\
3.4 \\
3.1 \\
3.2 \\
3.0 \\
3.3 \\
3.9 \\
4.6\end{array}$ & $\begin{array}{l}2.5 \\
2.4\end{array}$ & \begin{tabular}{|l}
\multicolumn{1}{|c}{0} \\
trace \\
0.10 \\
0.20 \\
0.32 \\
0.63 \\
0.82 \\
1.2 \\
1.7 \\
2.4 \\
3.6 \\
5.2 \\
5.4 \\
5.7 \\
5.4 \\
5.8 \\
8.1 \\
7.7 \\
6.5 \\
8.3
\end{tabular} & $\begin{array}{c}0 \\
\text { trace } \\
0.10 \\
0.20 \\
0.62 \\
1.23 \\
2.02 \\
4.1 \\
5.8 \\
8.2 \\
10.5 \\
13.5 \\
14.8 \\
15.5 \\
14.6 \\
15.8 \\
18.3 \\
17.4 \\
18.7 \\
22.6\end{array}$ \\
\hline
\end{tabular}

excretion. Even in this case it is doubtful whether the maximum concentration of the bile acids had been attained at the termination of the period of drainage inasmuch as the concentrations were continuing to increase at that time. However, the relative proportions of the various bile acids were rather constant after the twentieth day. The average proportion of cholic acid to desoxycholic acid to chenodesoxycholic acid for days $20,21,24$, and 25 was 3:0.98:0.74. Days 22 and 23 were omitted from the calculation because hog bile was ad- 
TABLE II

The excretion of conjugated bile acids in the choledochostomy drainage bile of patient C. D., and the effect of oral administration of desiccated hog bile

\begin{tabular}{|c|c|c|c|c|c|}
\hline \multirow{2}{*}{$\begin{array}{c}\text { Days } \\
\text { post- } \\
\text { opera- } \\
\text { tive }\end{array}$} & \multirow{2}{*}{$\begin{array}{l}\text { Hyodesoxy- } \\
\text { cholic } \\
\text { acid } \\
\text { content of } \\
\text { hog bile } \\
\text { adminis- } \\
\text { tered }\end{array}$} & \multicolumn{4}{|c|}{ Concentration of bile acids in drainage bile } \\
\hline & & $\begin{array}{l}\text { Total } \\
\text { bile } \\
\text { acids }\end{array}$ & $\begin{array}{c}\text { Total } \\
\text { conjugated } \\
\text { bile } \\
\text { acids }\end{array}$ & $\begin{array}{c}\text { Tauro- } \\
\text { conjugated } \\
\text { bile } \\
\text { acids }\end{array}$ & $\begin{array}{l}\text { Glyco- } \\
\text { conjugated } \\
\text { bile } \\
\text { acids }\end{array}$ \\
\hline & $\begin{array}{c}\text { millimoles } \\
\text { per day }\end{array}$ & \multicolumn{4}{|c|}{ millimoles per liter } \\
\hline $\begin{array}{c}2 \\
3-4 \\
5-6 \\
7-8 \\
9-10 \\
11 \\
12 \\
13 \\
14 \\
15 \\
16 \\
17 \\
18 \\
19 \\
20 \\
21 \\
22 \\
23 \\
24 \\
25\end{array}$ & $\begin{array}{l}0 \\
0 \\
0 \\
0 \\
0 \\
0 \\
0 \\
0 \\
0 \\
0 \\
0 \\
0 \\
0 \\
0 \\
0 \\
0 \\
2.8 \\
2.8 \\
0 \\
0\end{array}$ & $\begin{array}{c}0 \\
\text { trace } \\
0.10 \\
0.20 \\
0.62 \\
1.23 \\
2.02 \\
4.1 \\
5.8 \\
8.2 \\
10.5 \\
13.5 \\
14.8 \\
15.5 \\
14.6 \\
15.8 \\
18.3 \\
17.4 \\
18.7 \\
22.6\end{array}$ & $\begin{array}{c}0 \\
\text { trace } \\
0.06 \\
0.13 \\
0.45 \\
0.92 \\
1.55 \\
3.3 \\
4.8 \\
6.4 \\
8.5 \\
11.5 \\
12.7 \\
13.5 \\
13.0 \\
13.3 \\
15.9 \\
14.9 \\
15.1 \\
19.2\end{array}$ & $\begin{array}{l}0.02 \\
0.05 \\
0.18 \\
0.38 \\
0.61 \\
1.35 \\
2.1 \\
2.6 \\
3.8 \\
5.2 \\
5.9 \\
5.8 \\
5.9 \\
5.8 \\
5.6 \\
5.2 \\
6.8 \\
8.8\end{array}$ & $\begin{array}{r}0.04 \\
0.08 \\
0.27 \\
0.54 \\
0.94 \\
1.95 \\
2.7 \\
3.8 \\
4.7 \\
6.3 \\
6.8 \\
7.7 \\
7.1 \\
7.5 \\
10.3 \\
9.7 \\
8.3 \\
10.4\end{array}$ \\
\hline
\end{tabular}

ministered on those days. The proportions of these 3 bile acids in hepatic bile of this case are in good agreement with those obtained by Wieland et al $(9,21)$ by calculation from the isolation of bile acids from pooled samples of gallbladder bile obtained from human cadavers. However, the absolute concentrations of these bile acids obviously were smaller in hepatic bile than in gallbladder bile. On the other hand, these data for the relative proportions of the bile acids do not agree with data reported by Colp and Doubilet (22) for the ratios of cholic acid to "desoxycholic acid" in gallbladder bile of a series of cases. However, these authors stated that the method which they used for determination of "desoxycholic acid" was not specific for that acid and probably included chenodesoxycholic acid, lithocholic acid, and possibly other bile acids of unknown nature.

A considerable fraction of the bile acids excreted by C. D. (Table II) was unconjugated during the first 10 days following the operation, but the percentage of the total bile acids in the conjugated form rose to 85 during the latter part of the period of drainage. The average ratio of glyco-conjugated bile acids to tauro-conjugated acids was $1.3: 1$ in the bile of C. D. during periods when hog bile was not administered.

In the case of C. M. (Table VI) with apparently greater liver damage than C. D., recovery of the synthesis of bile acids was delayed longer, and the bile acid concentrations attained after 40 days were approximately $1 / 2$ those which occurred in the bile of C. D. after 20 days. During the first 3 weeks following the operation, the bile excreted by patient $C$. M. contained much sediment, and it was pale brown in color and possessed an offensive odor. Thereafter, there was progressive improvement in the appearance of the bile, and after approximately the thirty-fourth day, the bile was fairly clear and of normal appearance. This improvement in the appearance of the bile was accompanied by a rapid increase in the excretion of bile acids. Excretion of desoxycholic acid and other dihydroxycholanic acids (presumably chenodesoxycholic acid) by C. M. was resumed before the excretion of cholic acid. However, on days 39 and 40 the proportion of cholic acid to desoxycholic acid to chenodesoxycholic acid was $3: 1: 0.7$ which is in good agreement with the proportion found in the case of C. D. As late as the fourteenth and eighteenth days following the operation, 56 and 49 per cent of the total bile acids were unconjugated, but the percentage of unconjugated acids had decreased to an average of approximately 11 at the end of the period of drainage (calculated from the data for days 39 and 40 , during which ox bile was not administered). At this time the average glyco/tauro ratio was 1.91 : 1 (Table VII). Patient A. M. (Tables IV and V) was in rather

TABLE III

The enterohepatic circulation of glycohyodesoxycholic acid; patient $C . D$.

\begin{tabular}{|c|c|c|c|}
\hline $\begin{array}{l}\text { Glycohyodesoxy- } \\
\text { cholic acid } \\
\text { content of dried } \\
\text { hog bile } \\
\text { administered }\end{array}$ & $\begin{array}{l}\text { Duration of } \\
\text { enterohepatic } \\
\text { circulation }\end{array}$ & $\begin{array}{l}\text { Glycohyodesoxy- } \\
\text { cholic acid } \\
\text { content of bile } \\
\text { excreted } \\
\text { at end of } \\
\text { period of } \\
\text { circulation }\end{array}$ & $\begin{array}{l}\text { Loss of } \\
\text { glycohyodesoxy- } \\
\text { cholic acid } \\
\text { during } \\
\text { circulation }\end{array}$ \\
\hline millimoles & hours & millimoles & $\begin{array}{l}\text { percentage of } \\
\text { initial amount }\end{array}$ \\
\hline $\begin{array}{l}2.6 \\
4.75 \\
10.0\end{array}$ & $\begin{array}{l}24 \\
24 \\
24\end{array}$ & $\begin{array}{l}1.9 \\
2.9 \\
6.3\end{array}$ & $\begin{array}{l}27 \\
39 \\
37\end{array}$ \\
\hline $\begin{array}{l}2.6 \\
4.75\end{array}$ & $\begin{array}{l}48 \\
48\end{array}$ & $\begin{array}{l}1.0 \\
1.4\end{array}$ & $\begin{array}{l}61.5 \\
70.5\end{array}$ \\
\hline 4.75 & 96 & 0.5 & 89.5 \\
\hline
\end{tabular}


TABLE IV

Excretion of various bile acids in the choledochostomy drainage bile of patient $A$. M., and the effect of oral administration of desiccated hog bile

\begin{tabular}{|c|c|c|c|c|c|c|}
\hline \multirow[b]{2}{*}{$\begin{array}{c}\text { Days } \\
\text { post- } \\
\text { opera- } \\
\text { tive }\end{array}$} & \multirow{2}{*}{$\begin{array}{l}\text { Hyodesoxy- } \\
\text { cholic } \\
\text { acid } \\
\text { content of } \\
\text { hog bile } \\
\text { adminis- } \\
\text { tered }\end{array}$} & \multirow[b]{2}{*}{$\begin{array}{c}\text { Average } \\
\text { volume } \\
\text { of bile } \\
\text { excreted } \\
\text { per day }\end{array}$} & \multicolumn{4}{|c|}{$\begin{array}{l}\text { Concentration of bile acids in } \\
\text { drainage bile }\end{array}$} \\
\hline & & & $\begin{array}{c}\text { Cholic } \\
\text { acid }\end{array}$ & $\begin{array}{l}\text { Hyo- } \\
\text { desoxy- } \\
\text { cholic } \\
\text { acid }\end{array}$ & $\begin{array}{c}\text { Total } \\
\text { dihy- } \\
\text { droxy- } \\
\text { cho- } \\
\text { lanic } \\
\text { acids }\end{array}$ & $\begin{array}{c}\text { Total } \\
\text { bile } \\
\text { acids }\end{array}$ \\
\hline & $\begin{array}{c}\text { millimoles } \\
\text { per day }\end{array}$ & $m l$. & \multicolumn{4}{|c|}{ millimoles per liter } \\
\hline $\begin{array}{c}2 \\
3 \\
4 \\
6 \\
8 \\
10 \\
11 \\
12-13 \\
14-16 \\
17 \\
18 \\
19 \\
20-22 \\
23-26 \\
27-28 \\
29 \\
30\end{array}$ & $\begin{array}{l}0 \\
0 \\
0 \\
0 \\
0 \\
0 \\
0 \\
0 \\
0 \\
0 \\
0 \\
0 \\
7.34 \\
7.34 \\
7.34 \\
0 \\
0\end{array}$ & $\begin{array}{c}405 \\
450 \\
510 \\
500 \\
545 \\
630 \\
710 \\
790 \\
850 \\
730(?) \\
810 \\
884 \\
1,030 \\
1,120 \\
1,140 \\
920 \\
895\end{array}$ & $\begin{array}{c}0 \\
0 \\
0 \\
0 \\
0 \\
\text { trace } \\
\text { trace } \\
1.47 \\
2.94 \\
3.69 \\
5.05 \\
8.12 \\
10.8 \\
10.8 \\
12.7 \\
15.1 \\
16.5\end{array}$ & $\begin{array}{l}0 \\
0 \\
0 \\
0 \\
0.1 \\
0.1 \\
0.1 \\
0.19 \\
0.21 \\
0.08 \\
0.12 \\
0.13 \\
5.1 \\
5.6 \\
5.2 \\
0.22 \\
0.20\end{array}$ & \begin{tabular}{|l|} 
trace \\
0.45 \\
0.62 \\
1.45 \\
2.85 \\
3.92 \\
5.10 \\
4.72 \\
4.26 \\
2.50 \\
3.82 \\
4.06 \\
8.70 \\
9.14 \\
8.72 \\
5.87 \\
7.04
\end{tabular} & $\begin{array}{c}\text { trace } \\
0.45 \\
0.62 \\
1.45 \\
2.85 \\
3.92 \\
5.1 \\
6.2 \\
7.2 \\
6.2 \\
8.9 \\
12.2 \\
19.5 \\
19.9 \\
21.4 \\
21.0 \\
23.5\end{array}$ \\
\hline
\end{tabular}

poor condition. Nevertheless, the excretion of cholic acid was resumed almost as soon after operation as occurred in the case of C. D., and the recovery of the excretion of dihydroxycholanic acids actually was more rapid than in the case of C. D. In fact, it was more rapid than occurred in any of the other cases which we investigated. Unfortunately, analyses for desoxycholic acid were not conducted on samples of bile from A. M., therefore the nature of the dihydroxycholanic acids was not determined. Again a large fraction of the total bile acids was unconjugated during the first six days after the operation, but thereafter recovery of the ability to conjugate the bile acids was rapid.

(2) Excretion of bile acids in drainage bile following oral administration of desiccated bile: Following oral administration of dried gallbladder bile of the hog, ${ }^{6}$ excretion of hyodesoxycholic acid, the predominant bile acid of hog bile, in the choledochostomy drainage bile, commenced after 1 to 2 hours. Thereafter, the excretion rose to a peak

\footnotetext{
6 Preparations of desiccated gallbladder bile of the hog (trade name, Desicol) and the ox were supplied by Parke, Davis and Company.
}

TABLE V

The excretion of conjugated bile acids in the choledochostomy drainage bile of patient $A$. M., and the effect of oral administration of desiccated hog bile

\begin{tabular}{|c|c|c|c|c|c|}
\hline \multirow{2}{*}{$\begin{array}{l}\text { Days } \\
\text { post- } \\
\text { opera- } \\
\text { tive }\end{array}$} & \multirow{2}{*}{$\begin{array}{l}\text { Hyodesoxy- } \\
\text { cholic } \\
\text { acid } \\
\text { content of } \\
\text { hog bile } \\
\text { adminis- } \\
\text { tered }\end{array}$} & \multicolumn{4}{|c|}{ Concentration of bile acids in drainage bile } \\
\hline & & $\begin{array}{l}\text { Total } \\
\text { bile } \\
\text { acids }\end{array}$ & $\begin{array}{c}\text { Total } \\
\text { conjugated } \\
\text { bile } \\
\text { acids }\end{array}$ & $\begin{array}{c}\text { Tauro- } \\
\text { conjugated } \\
\text { bile } \\
\text { acids }\end{array}$ & $\begin{array}{c}\text { Glyco- } \\
\text { conjugated } \\
\text { bile } \\
\text { acids }\end{array}$ \\
\hline & $\begin{array}{c}\text { millimoles } \\
\text { per day }\end{array}$ & \multicolumn{4}{|c|}{ millimoles per liter } \\
\hline $\begin{array}{c}2 \\
3 \\
4 \\
6 \\
8 \\
10 \\
11 \\
12-13 \\
14-16 \\
17 \\
18 \\
19 \\
20-22 \\
23-26 \\
27-28 \\
29 \\
30\end{array}$ & $\begin{array}{l}0 \\
0 \\
0 \\
0 \\
0 \\
0 \\
0 \\
0 \\
0 \\
0 \\
0 \\
0 \\
7.34 \\
7.34 \\
7.34 \\
0 \\
0\end{array}$ & $\begin{array}{c}\text { trace } \\
0.45 \\
0.62 \\
1.45 \\
2.85 \\
3.92 \\
5.1 \\
6.2 \\
7.2 \\
6.2 \\
8.9 \\
12.2 \\
19.5 \\
19.9 \\
21.4 \\
21.0 \\
23.5\end{array}$ & $\begin{array}{c}0 \\
\text { trace } \\
0.25 \\
0.79 \\
1.95 \\
3.42 \\
5.0 \\
6.03 \\
6.98 \\
6.10 \\
8.80 \\
11.8 \\
19.6 \\
19.8 \\
21.2 \\
20.1 \\
21.9\end{array}$ & $\begin{array}{c}0.12 \\
0.31 \\
0.70 \\
1.24 \\
2.10 \\
3.30 \\
3.21 \\
2.80 \\
4.23 \\
5.66 \\
7.40 \\
7.60 \\
8.60 \\
9.4 \\
10.3\end{array}$ & $\begin{array}{c}0.13 \\
0.48 \\
1.25 \\
2.18 \\
2.90 \\
2.73 \\
3.77 \\
3.30 \\
4.57 \\
6.14 \\
12.2 \\
12.2 \\
12.6 \\
10.7 \\
11.6\end{array}$ \\
\hline
\end{tabular}

at about 7 to 10 hours, then gradually declined, the total period of excretion comprising 18 to 20 hours. $^{7}$ In Table I (case C. D.) the concentration of hyodesoxycholic acid in the bile collected during a 24-hour period following administration of hog bile is recorded, together with the total volume of bile. From these data the total amounts of hyodesoxycholic acid excreted were calculated. The average excretion of hyodesoxycholic acid by this patient was 87.5 per cent of the amount admin-

7 This period of circulation or total "clearance-time" is considerably longer than that reported for man by Josephson (23), but it is comparable with the data for hogs (12) and for dogs $(24,25)$. Josephson calculated the clearance-time by observing the time required for biliary excretion of the natural cholates to return to the normal secretory level from the high level induced by recirculation of bile or by administration of cholates. Inasmuch as the normal rate of excretion of cholates is subject to some variation, it would be difficult to determine the total clearance-time precisely by that method. On the other hand, the time required for attainment of the peak of clearance of hyodesoxycholate in our experiments was comparable with the total clearance-time reported by Josephson. It is probable that enterohepatic circulation may have been somewhat delayed in the patients of our series as compared with the relatively normal subjects studied by Josephson. In addition, the circulation of hyodesoxycholate may require a longer time than the circulation of the natural cholates. 
istered. In the case of A. M. (Table IV), hog bile was administered daily, as recorded in column 2 , from the twentieth to the twenty-eighth day. The drainage bile was pooled for the intervals shown in column 1 , and the average daily volume and average daily excretion were calculated. The average excretion of hyodesoxycholic acid by this patient was 78.5 per cent of the amount administered. In Tables II and $\mathrm{V}$ it can be seen that in the 24-hour period following administration of hog bile there was an increase in the ratio of glycoconjugated acids to tauro-conjugated. Inasmuch as hyodesoxycholic acid of hog bile is conjugated solely with glycine, this increase in the glyco/ tauro ratio of the drainage bile, together with the excretion of hyodesoxycholic acid, suggests strongly that glycohyodesoxycholic acid was absorbed from the intestine and excreted unchanged in the drainage bile. The efficiency of utilization of this foreign bile acid by these patients appears to be somewhat less than the efficiency with which glycocholic acid was handled by hogs with biliary fistulae (12). However, it is doubtful whether the bile collected by drainage through a T-tube represents the entire biliary secretion even under carefully supervised conditions.

TABLE VI

Excretion of various bile acids in the choledochostomy drainage bile of patient $C$. M., and the effect of oral administration of desiccated ox bile

\begin{tabular}{|c|c|c|c|c|c|c|}
\hline \multirow{2}{*}{$\begin{array}{l}\text { Days } \\
\text { post- } \\
\text { opera- } \\
\text { tive }\end{array}$} & \multirow{2}{*}{$\begin{array}{l}\text { Cholic } \\
\text { acid } \\
\text { content of } \\
\text { ox bile } \\
\text { adminis- } \\
\text { tered }\end{array}$} & \multirow[b]{2}{*}{$\begin{array}{l}\text { Volume } \\
\text { of bile } \\
\text { excreted } \\
\text { per day }\end{array}$} & \multicolumn{4}{|c|}{$\begin{array}{c}\text { Concentration of bile acids in } \\
\text { drainage bile }\end{array}$} \\
\hline & & & $\begin{array}{c}\text { Cholic } \\
\text { acid }\end{array}$ & $\begin{array}{l}\text { Des- } \\
\text { oxy- } \\
\text { cholic } \\
\text { acid }\end{array}$ & $\begin{array}{c}\text { Total } \\
\text { dihy- } \\
\text { droxy- } \\
\text { cho- } \\
\text { lanic } \\
\text { acids }\end{array}$ & $\begin{array}{l}\text { Total } \\
\text { bile } \\
\text { acids }\end{array}$ \\
\hline & $\begin{array}{c}\text { millimoles } \\
\text { per day }\end{array}$ & $m l$. & \multicolumn{4}{|c|}{ millimoles per liter } \\
\hline $\begin{array}{l}2 \\
10 \\
14 \\
18 \\
19 \\
21 \\
22 \\
24 \\
25 \\
26 \\
28 \\
30 \\
32 \\
34 \\
36 \\
38 \\
39 \\
40\end{array}$ & $\begin{array}{c}0 \\
0 \\
0 \\
0 \\
1.2 \\
1.2 \\
1.2 \\
1.2 \\
1.2 \\
1.2 \\
1.2 \\
1.2 \\
1.2 \\
1.2 \\
1.2 \\
1.2 \\
0 \\
0\end{array}$ & $\begin{array}{r}615 \\
705 \\
640 \\
620 \\
990 \\
960 \\
1,005 \\
1,100 \\
910 \\
940 \\
915 \\
898 \\
930 \\
905 \\
900 \\
895 \\
905 \\
890\end{array}$ & $\begin{array}{c}0 \\
0 \\
\text { trace } \\
0.1 \\
0.9 \\
1.2 \\
1.4 \\
1.3 \\
1.8 \\
2.4 \\
3.1 \\
4.3 \\
5.2 \\
5.9 \\
6.3 \\
6.6 \\
5.7 \\
5.9\end{array}$ & $\begin{array}{l}0.08 \\
0.11 \\
0.32 \\
0.37 \\
0.48 \\
0.51 \\
0.39 \\
0.56 \\
0.49 \\
0.65 \\
0.78 \\
1.12 \\
1.43 \\
1.74 \\
1.82 \\
1.81 \\
1.91 \\
2.02\end{array}$ & $\begin{array}{l}0.12 \\
0.19 \\
0.55 \\
0.69 \\
0.81 \\
0.85 \\
0.80 \\
0.92 \\
0.90 \\
1.10 \\
1.35 \\
2.04 \\
2.58 \\
3.11 \\
3.23 \\
3.10 \\
3.29 \\
3.36\end{array}$ & $\begin{array}{l}0.12 \\
0.19 \\
0.55 \\
0.79 \\
1.71 \\
2.05 \\
2.20 \\
2.22 \\
2.70 \\
3.50 \\
4.45 \\
6.34 \\
7.78 \\
9.01 \\
9.53 \\
9.70 \\
8.99 \\
9.26\end{array}$ \\
\hline
\end{tabular}

It was of considerable interest to study the enterohepatic circulation of bile acids in these patients. The hyodesoxycholic acid of hog bile provided a "tracer" for study of such circulation since this bile acid is foreign to the normal biliary secretion of man. These studies were conducted as described in our paper on enterohepatic circulation in hogs (12). Following oral administration of hog bile containing the quantity of glycohyodesoxycholic acid recorded in column 1 of Table III, the external choledochostomy drainage tube was clamped shut in order to direct the flow of bile into the intestine. Following the period of circulation recorded in column 2 , the clamp was removed and the bile was collected for a 20-hour period for determination of the amount of hyodesoxycholic acid remaining at that time (column 3 ). The percentage loss of glycohyodesoxycholic acid is recorded in column 4 . Even after 4 days, some of the hyodesoxycholic acid remained in the circuit. Again the efficiency of circulation was somewhat less than that of the hog, but, nevertheless, such circulation provides an important mechanism for the conservation of bile acids.

Inasmuch as the bile acid composition of ox bile is very similar to that of man, it was more difficult to assess quantitatively the effect of administration of ox bile to these patients. However, it is appar-

TABLE VII

The excretion of conjugated bile acids in the choledochostomy drainage bile of patient $C$. M., and the effect of oral administration of desiccated ox bile

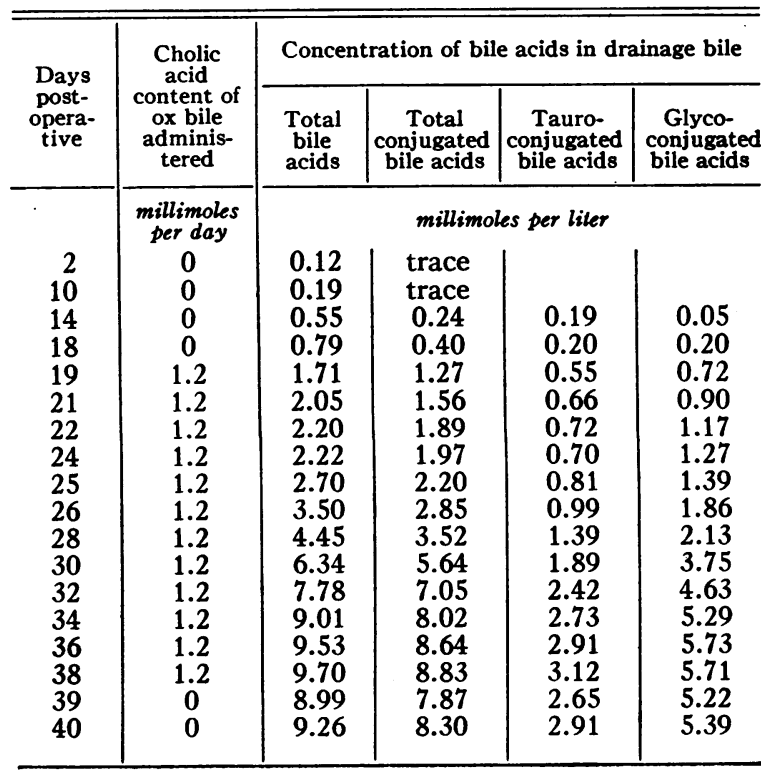


TABLE VIII

Excretion of cholic acid in the choledochostomy drainage bile of patient $F$. W., and the effect of oral administration of desiccated ox bile

\begin{tabular}{c|c|c|c}
\hline $\begin{array}{c}\text { Days } \\
\text { post- } \\
\text { operative }\end{array}$ & $\begin{array}{c}\text { Cholic acid } \\
\text { content of } \\
\text { ox bile } \\
\text { administered }\end{array}$ & $\begin{array}{c}\text { Volume } \\
\text { of bile } \\
\text { excreted } \\
\text { per day }\end{array}$ & $\begin{array}{c}\text { Concentration } \\
\text { of cholic } \\
\text { acid in } \\
\text { drainage bile }\end{array}$ \\
\hline millimoles per day & ml. & millimoles per liter \\
2 & 0 & 690 & 0 \\
3 & 0 & 520 & 0 \\
4 & 0 & 580 & 0 \\
5 & 0 & 625 & trace \\
6 & 0 & 680 & trace \\
7 & 0 & 610 & 0.12 \\
8 & 1.42 & 950 & 1.23 \\
9 & 1.42 & 1,025 & 1.39 \\
10 & 1.42 & 1,190 & 1.24 \\
11 & 1.42 & 1,080 & 1.47 \\
12 & 1.42 & 1,140 & 1.66 \\
\hline
\end{tabular}

ent from Tables VI and VIII that administration of desiccated ox bile to these patients, in the early post-operative period before recovery of the excretion of bile acids, was followed by an immediate increase in the excretion of bile acids, particularly cholic acid. Inasmuch as the average ratio of cholic acid to desoxycholic acid is 5.5:1 in ox bile (10) as compared to $3: 1$ in the bile of man, it is

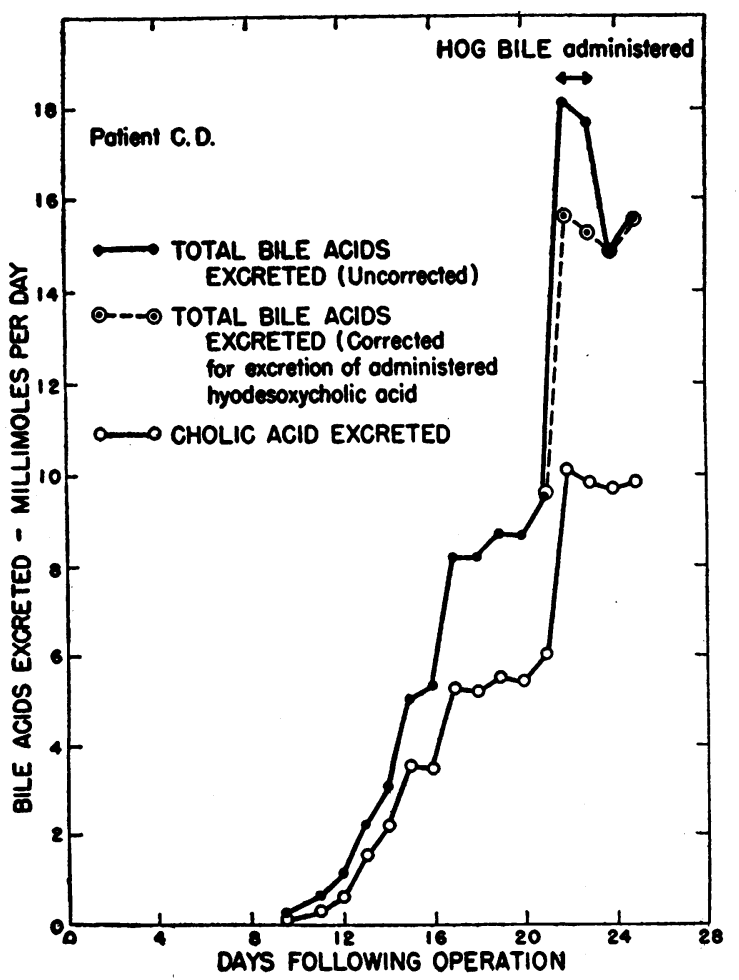

FIg. 1 to be expected that the administration of ox bile to human patients would cause a proportionately greater increase in cholic acid. Administration of ox bile did not produce a significant change in the glyco/tauro ratio in the bile of C. M. (Table VII) if the period from days 30 to 38 , during which ox bile was administered, is compared with days 39 and 40, during which administration of ox bile was discontinued. This is to be expected in view of the similarity in the conjugation of bile acids of man and the ox.

Administration of either hog bile or ox bile to these patients produced an increase in the volume of bile excreted during the ensuing 24 hours. The question of the effect of the administration of animal bile upon the synthesis of bile acids by the patient is important but is difficult to decide from our data inasmuch as the synthesis of bile acids was increasing progressively in most of the cases before animal bile was administered. The quantity of bile acids excreted per day can be calculated from the corresponding data for the volume of bile and the concentrations of the bile acids. Such data for the quantity of bile acids excreted in the bile per day are recorded for three of the cases in Figures 1 to 3. Also, in these figures data for bile

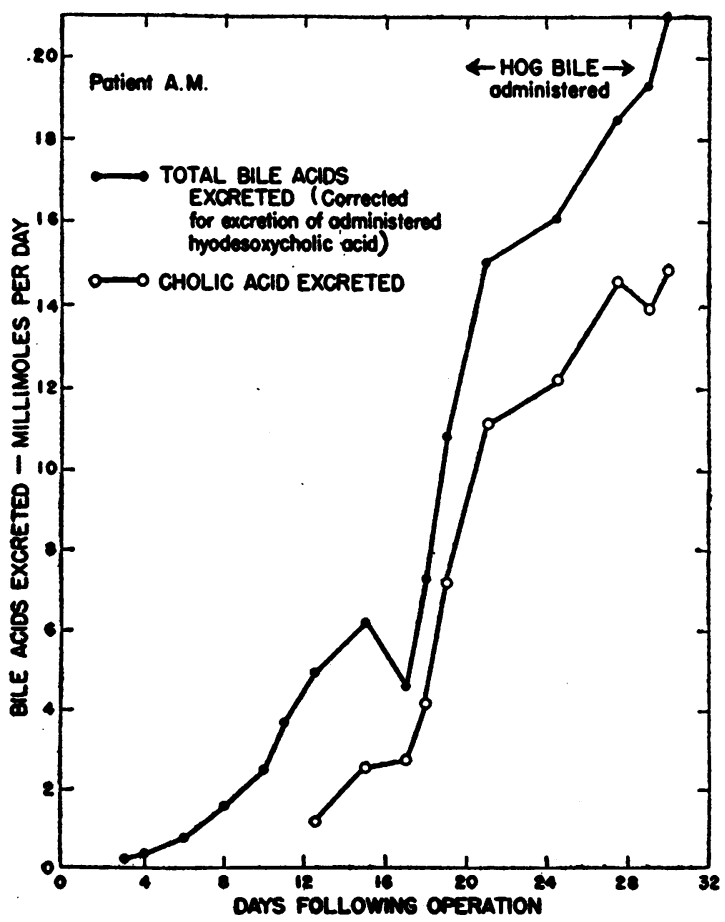

Fig. 2 


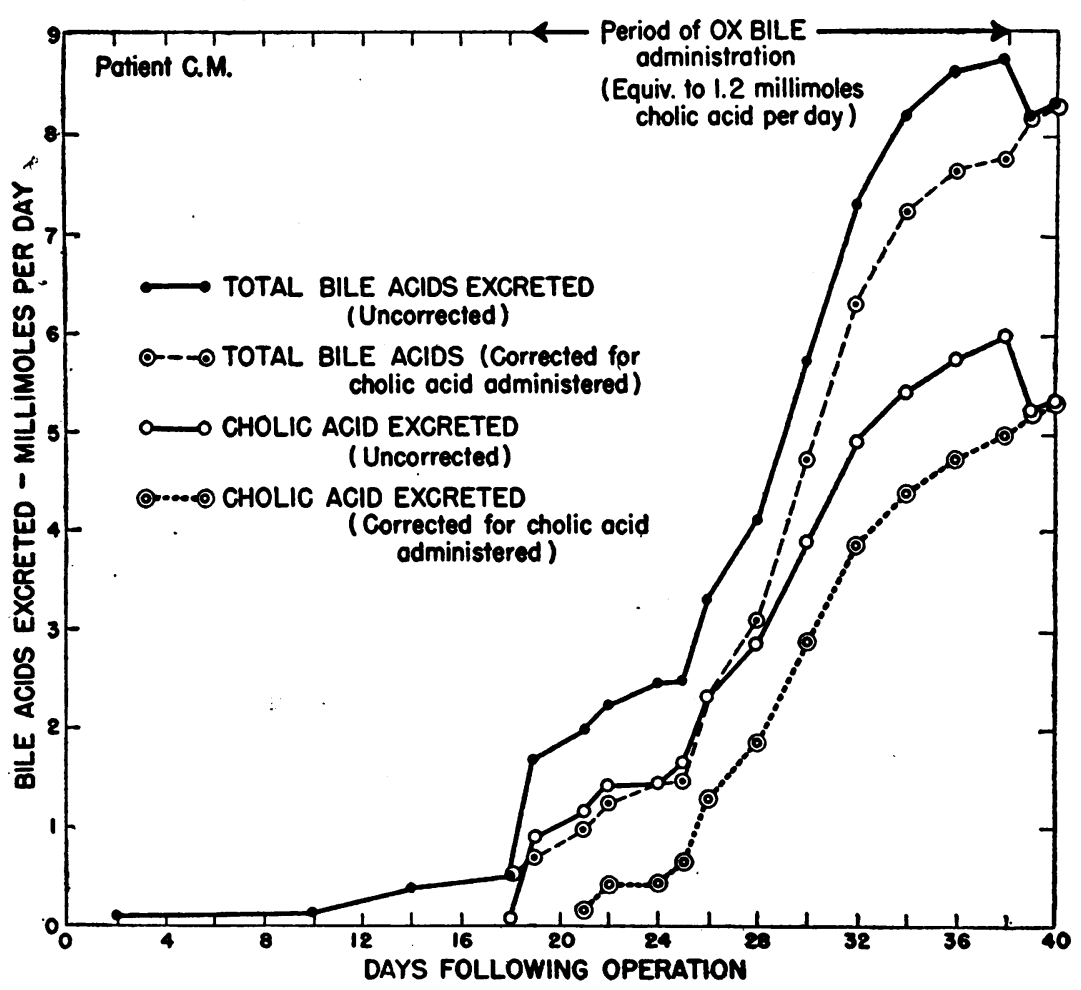

FIG. 3

acid excretion are presented which have been "corrected" for the excretion of the bile acids contained in the administered animal bile, thus yielding data for the production of bile acids by the patient. It can be observed from these corrected curves that administration of bile of the ox or the hog did not depress the production of bile acids by the patients although there was a slight leveling of the slope of the curves in the case of A. M. (Figure 2) who received the largest doses of hog bile. On the other hand, there appears to have been some stimulation of bile acid production in the cases of C. D. (Figure 1) and C. M. (Figure 3). However, such a conclusion would seem to be unwarranted from the limited data available in view of the difficulties mentioned above. In the case of C. D. (Figure 1), the sharp increase in excretion of bile acids upon administration of hog bile might have been due to release of a slight obstruction to the flow of bile as a result of the pressure of the increased bile flow caused by the administered hog bile. However, the increase in concentration of the bile acids, in addition to the increase in volume of bile excreted, following ad- ministration of hog bile (Table $\mathrm{I}$ ), is somewhat suggestive of a stimulatory effect. Nevertheless, if such an effect occurred, it must be assumed that it persisted after cessation of hog bile administration in view of the continued increase in the concentration of the bile acids (Table I) and of the maintenance of the quantity of bile acids excreted (Figure 1). In the case of C. M. (Tables VI and VII and Figure 3 ) there was progressive increase in the excretion of bile acids throughout the period of ox bile administration, and the production of bile acids by the patient was maintained during the 2 days of observation following cessation of ox bile administration (corrected curves of Figures 3). Again, stimulation of bile acid production cannot be claimed since similar progressive increases in bile acid production have been observed in other patients during periods in which ox bile was not administered. During the period of observation this patient did not attain so high a level of bile acid excretion as did patients C. $D$. and A. M., but, as mentioned previously, the bile of this patient was quite abnormal during the first 3 weeks (improving slowly thereafter) suggesting 
a pathological state of the liver or bile ducts, or both.

While the possible stimulation of bile acid production by administration of animal bile to these patients cannot be decided conclusively from these data, it seems desirable to emphasize again those effects which are demonstrated unequivocally, i.e., the increase in volume of bile-flow and the absorption and reexcretion of the bile acids supplied in the animal bile. The intestinal absorption of these "foreign" bile acids by the patients suggests that these animal biles can be used successfully in replacement therapy. Additional evidence of their successful function in replacing the bile of the patient has been provided by observations of increases in the values for prothrombin assays during periods when animal bile was administered.

In previous papers $(12,13)$ we have demonstrated that normally the concentration of cholates in blood of the peripheral circulation is less than 1 mgm. per $100 \mathrm{ml}$., but appreciably greater concentrations of cholates appear in peripheral blood of men and dogs with biliary obstruction $(13,23)$ except in those cases in which the obstruction is of such duration that the damaged liver has lost the ability to synthesize cholates. However, even in the latter condition, the oral administration of cholates to animals with biliary obstruction is followed by the appearance of cholates in the circulation $(12,13)$. In Table IX there are recorded the results of analyses for cholates in blood samples obtained from a patient with biliary obstruction.

This patient (C. S.), a 45-yr.-old black male, had had a cholecystectomy performed 6 months previous to admission, and an attempted drainage of his common duct one month after the cholecystectomy because of increasing jaundice. Following his operation a small amount of bile drained from his wound but his jaundice did not disappear. At the time of admission his skin had been markedly icteric for 6 months, he had had frequent intermittent attacks of upper abdominal pain associated with chills and fever, and suffered intense itching. His stools had been persistently acholic. Shortly after admission the Van den Bergh was direct, immediate with $9.3 \mathrm{mgm}$. bilirubin per 100 ml. of blood.

He was operated upon 37 days after admission
TABLE IX

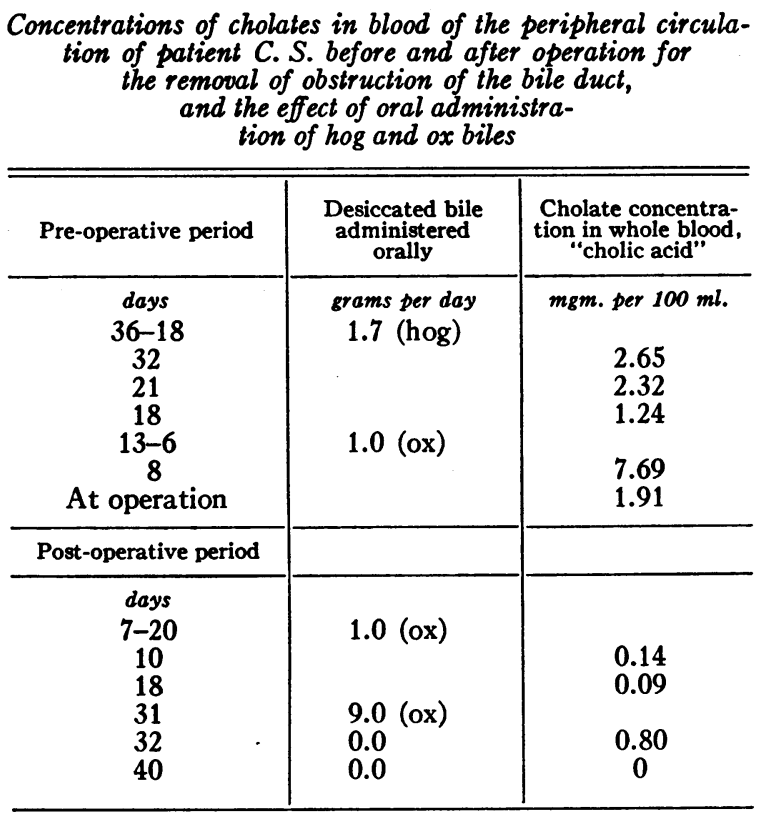

and no evidence of the common duct was found. There was a small scarred area in the hilus of the liver from which thin, pale green bile was aspirated. The duodenum was sufficiently mobilized to permit direct anastomosis, over a pezzar catheter, with the hepatic duct, the catheter being brought out to the anterior abdominal wall through the stomach. Drainage of bile through the catheter was continued for 6 weeks. The catheter was then removed, and within 24 hours drainage from the wound had stopped.

Samples were obtained during pre- and postoperative periods and during the administration of desiccated bile of the hog and the ox. During the thirty-sixth to the eighteenth day before the operation there was a decline in the concentration of cholates in the peripheral blood which probably was indicative of a decline in the ability of the liver to synthesize cholates. This decline in the concentration of cholates occurred during a period when desiccated hog bile was being administered orally. However, hog bile does not contain cholates $(8,12)$, and our method $(13)$ was specific for the determination of that bile salt, either unconjugated or conjugated with glycine or taurine. At the time of these studies, we did not have available a method for the determination of hyodesoxycholates in blood; therefore, we were un- 
able to study the interesting question of the possible appearance of that bile salt of the hog in the peripheral circulation of obstructed patients receiving hog bile by mouth. On the eighteenth day (pre-operative), administration of hog bile was discontinued. During the period from the thirteenth to the sixth pre-operative day, a daily oral dose of 1 gram of desiccated ox bile (which contains cholates) was administered. The concentration of cholate in the peripheral blood had risen to $7.69 \mathrm{mgm}$. per $100 \mathrm{ml}$. by the eighth pre-operative day. Administration of ox bile was discontinued on the sixth day before operation, and at the time of operation the concentration of cholate had declined again to $1.91 \mathrm{mgm}$. per $100 \mathrm{ml}$. of blood. After removal of the obstruction by operation, the concentration of cholate in the peripheral circulation remained low even when large doses of dried ox bile were administered orally.

\section{SUMMARY}

Bile samples collected post-operatively by choledochostomy drainage from a series of 11 cases were analyzed for cholic, desoxycholic, and total dihydroxycholanic acids and for glyco, tauro, and total conjugated bile acids. A period of 10 to 20 days after operation usually elapsed before resumption of synthesis of these bile acids by patients whose biliary tracts had been severely obstructed. In some of the cases, the excretion of desoxycholic acid and the total dihydroxycholanic acid fraction was resumed somewhat earlier than the excretion of cholic acid. In most cases; a considerable fraction of the bile acids was unconjugated during the first week or two following the operation, but usually recovery of the ability to conjugate the bile acids (with glycine or taurine) did not lag far behind recovery of the synthesis of the steroid nucleus of the bile acids.

After a recovery period of 20 to 25 days, the average proportion of cholic acid to desoxycholic acid to chenodesoxycholic acid was $3: 1: 0.75$ in the bile of a patient with apparently minimal liver damage. Similar proportions between these bile acids were obtained for most of the other cases during the late post-operative period, but the absolute concentrations of the bile acids were smaller in the bile of those patients with the greatest liver damage.
Oral administration of desiccated gallbladder bile of the hog to these patients was followed by the biliary excretion of hyodesoxycholic acid, a bile acid which normally is foreign to the bile of man but which is a principal component of hog bile in which it is found conjugated with glycine. There also was an increase in the glyco/tauro coefficient which suggests that glycohyodesoxycholic acid was absorbed and reexcreted unchanged in the drainage bile. This foreign bile acid was handled fairly efficiently in the enterohepatic circulation, a portion remaining in the circuit even after 4 days.

Following oral administration of desiccated gallbladder bile of the ox to these patients, there were increases in the excretion of cholic and desoxycholic acids which were proportional to the amounts of these bile acids in the administered ox bile.

Preparations of desiccated bile of the hog and the ox provide a convenient and effective means for replacement of bile during choledochostomy drainage. Both preparations are well tolerated, both stimulate an increase in the volume of bileflow, and both provide bile acids which are effective in supplementing the output of bile acids by the patient, apparently without inhibiting the synthesis of bile acids.

Cholates normally are present in blood of the peripheral circulation in concentrations less than $1 \mathrm{mgm}$. per $100 \mathrm{ml}$., but the concentrations increase appreciably when the biliary tract is obstructed unless the synthesis of cholates is decreased by liver damage. Even in the latter case, the oral administration of cholates, or ox bile containing cholates, produces an increase in the concentration of cholates in the peripheral circulation in contrast to the absence of this effect when the biliary tract is not obstructed.

\section{CASE HISTORIES}

Case 1.-F. W., a 53-year-old white male, entered the hospital 5-11-40 because of fever, chills of 5 days' duration, and epigastric pain for 3 days. He had noticed a yellow tinge to his skin for several days. More than a year previous to this time he had stopped eating pork; over this same period he had suffered heart burn regularly. He had lost 25 pounds in the past year.

Temperature $100.8^{\circ}$, pulse 100 , respiration 20 , blood pressure 106/60. Icterus was obvious. There was rigidity in the right upper quadrant with tenderness in this area. The liver was $2 \mathrm{~cm}$. below the costal margin. 
There was a right inguinal hernia present. There was stasis dermatitis on both legs.

Van den Bergh $1.3 \mathrm{mgm}$., direct; blood urea nitrogen 143 ; serum albumin 4.6 per cent, globulin 4.0 per cent. Urine showed only faint trace of albumin consistently. Hb 11.5 grams, RBC 2,240,000, WBC 6,400 , polys 85 per cent. Opaque shadows in flat film suggested gallstones. The patient was treated symptomatically, given blood transfusions and fluid by vein. Despite the high, maintained blood urea the patient appeared moderately improved, and it was believed that the high urea was associated with liver disease.

Operation was performed on 5-21-40, at which time a lobulated scarred liver was found. Marked adhesions were present about the gallbladder and common duct. The gallbladder was exposed with some difficulty. It contained numerous small stones. Despite the need for common duct exploration, on account of the difficulties encountered, it was decided to drain the common duct through the dilated cystic duct. The proximal portion of the gallbladder and the cystic duct were sutured about the tube for future use if needed. Bile readily drained from the tube. The patient was given several transfusions of whole blood post-operatively. His blood pressure quickly becoming stabilized at $110 / 60$. Within five days the temperature returned to normal, the highest post-operative temperature being $102^{\circ}$. Despite the generally improved appearance of the patient, he complained of feeling weak and ate very little. Within 2 weeks post-operatively it became more difficult to get him to take nourishment by mouth. The tube was removed 21 days after operation. The patient expired on 6-13-40. Postmortem examination was not performed.

Case 2. C. M., a 50-year-old colored housewife entered the hospital 10-26-40, because of acute epigastric pain of 10 hours' duration. The pain radiated to the interscapular area and was associated with nausea and vomiting. For 15 years she had had intolerance to fatty foods. On admission she was restless, moving about with recurrent attacks of acute pain. There was rigidity of the right upper quadrant. Temperature $102^{\circ}$, pulse 100 , respiration 24 , blood pressure $90 / 60$.

Shortly after admission following administration of morphine sulphate, nitroglycerine and intravenous fluids, the blood pressure was $150 / 104$ and the patient became more comfortable. Hb 11.5 grams, WBC 7,300, urinalysis showed faint trace of albumin. Van den Bergh direct, immediate, $1.9 \mathrm{mgm}$ per $100 \mathrm{ml}$. All evidence of icterus gone, icteric index being 7.5.; operation was performed on 11-9-40 at which time a chronically inflamed gallbladder was removed and the dilated thickened common duct was explored. A T-tube was placed in the common duct for drainage. The capsule of the liver was thickened and there was increased trabeculation of the liver. No obstruction was found. Following operation, the patient's blood pressure dropped to $90 / 50$, but following plasma infusion, rose to $140 / 100$. After a few stormy days, her temperature, pulse, respiration, and blood pressure became stabilized at normal levels. Drainage was carried on for 40 days. The patient was discharged to the outpatient department.

Case 3. C. D., a 58-year-old white woman, was admitted to the medical service because of severe epigastric pain of 1 day's duration. This was but one of many repeated similar attacks which she had had for the preceeding 7 years. These attacks usually began as pain in the epigastrium or in the right upper quadrant. There had been no jaundice noted, but there had been chills and fever on occasion, and she had noted dark urine. Temperature $98.4^{\circ}$, pulse 98 , respiration 20 , blood pressure $130 / 70$, weight $881 / 2$ pounds.

On physical examination there were definite tenderness and slight rigidity of the right upper quadrant. The right kidney was palpable and there was tenderness in the right costovertebral angle. The liver was palpable 2 centimeters below the costal margin. Other positive findings were a right inguinal hernia and external hemorrhoids. Icterus was not obvious clinically. The Kline test was negative, hemoglobin 11 grams $\mathrm{RBC} 4,340,000$, WBC 11,800 , polys 86 per cent. Serum albumin 3.5 per cent, globulin 1.6 per cent, van den Bergh $0.6 \mathrm{mgm}$. per $100 \mathrm{cc}$. Flat film of the abdomen revealed 2 large radiopaque shadows which were interpreted as gallstones. Barium study revealed diverticula of the duodenum. Intravenous pyelogram revealed nothing unusual.

Immediately following admission, pain and tenderness subsided, but 11 days later she had pain in the epigastrium, vomiting, and return of tenderness associated with chills and a fever of $103^{\circ}$. This promptly subsided to recur 2 days later. Similar but milder attacks occurred every 2 to 4 days thereafter until she was operated upon 1-8-40. At operation a contracted thickened gallbladder was found with a $11 / 2 \mathrm{~cm}$. stone imbedded in the fundus. The common duct measured more than $2 \mathrm{~cm}$. in diameter and was filled with a large, putty-like mass, greenish brown in color, which formed a cast of the common duct. This material was removed, the duct washed clear, and a large T-tube placed in the common duct. The gallbladder was removed. The liver was found to be large and extended $4 \mathrm{~cm}$. below the costal rim. The surface was finely granular and green tinted.

Following operation the patient's condition was satisfactory. Drainage was continued for 25 days, following which, after determining patency of the duct, the tube was removed. The patient returned a year later for repair of her inguinal hernia at which time she had had no recurrence of her symptoms and was able to eat without restriction.

Case 4. A. M., a 61-year-old Turkish male, was admitted to the medical service on 10-23-38 because of right upper quadrant pain, jaundice, and vomiting. For 2 years previously he had had intermittent attacks of right upper quadrant pain with nausea and vomiting. He had lost seventy pounds in the 2 years, but stated he ate very little for fear of precipitating an attack. Two days previously he had had an attack which was more severe than usual which was accompanied with chills and fever, and he noted for the first time that he was jaundiced. Upon 
examination he was found to be markedly icteric and the skin and mucus membranes were quite dry. Temperature $99^{\circ}$, pulse 100 , respiration 22 , blood pressure $100 / 70$. Moist rales were present over the right base posteriorly. The liver edge could be felt $3 \mathrm{~cm}$. below the costal margin in the midclavicular line and there were marked tenderness and moderate rigidity of the right upper quadrant. The spleen was palpable on deep inspiration. There was pitting edema of dependent parts. On admission, the urine contained bile, albumin 4 and an occasional white cell. Hb 12.5 grams, RBC 4,300,000, WBC 31,300 , polys 96 per cent. Kline test negative, van den Bergh immediate, direct, $4.5 \mathrm{mgm}$. There was a trace of urobilinogen in the urine, blood cholesterol $228 \mathrm{mgm}$. On 11-14-38, three weeks after admission, his white count was 8,800 and his hemoglobin 8.0 grams, serum albumin 3.3, globulin 2.8, clotting time $3 \frac{1}{2}$ minutes, bleeding time 4 minutes, 10 seconds, prothrombin 52 per cent.

The patient was treated symptomatically. He was given 0.4 gram pig bile t.i.d. with several experimental preparations of vitamin $\mathrm{K}$ given orally.

Just preceding operation, which was performed on 117-39, the prothrombin was 58 per cent, hemoglobin 12.6 grams, WBC 7,800, van den Bergh $0.75 \mathrm{mgm}$. At operation the liver appeared but slightly enlarged, was paler than normal, and the capsule was moderately thickened. The gallbladder contained numerous stones and was removed. The common duct was thickened and admitted the index finger easily. Three stones were removed from the duct, following. which the probe passed easily into the duodenum and into the liver. A T-tube was sutured into the common duct and brought out through the abdominal wall. Following operation he had no unusual difficulties and was discharged in good condition.

\section{BIBLIOGRAPHY}

1. Ravdin, I. S., Johnston, C. G., Riegel, C., and Wright, S. L., A study of human liver bile after release of common duct obstruction. J. Clin. Invest., 1933, $12,659$.

2. Ravdin, I. S., Riegel, C., Johnston, C. G., and Morrison, P. J., Studies in biliary tract disease. J. A. M. A., 1934, 103, 1504.

3. Irvin, J. L., Merker, H., Anderson, C. E., and Johnston, C. G., The comparison of desiccated and normal hog gallbladder bile. J. Biol. Chem., 1939, 131, 439.

4. Johnston, C. G., Preoperative and postoperative treatment in cases of obstructive jaundice. Surgery, 1938, 3, 875.

5. Winfield, J. M., The use of dried bile as a therapeutic agent. J. Michigan M. Soc., 1938, 37, 798.

6. Sobotka, H., Physiological Chemistry of the Bile. Williams and Wilkins, Baltimore, 1937.

7. Schoenheimer, R., Andrews, E., and Hrdina, L., Uber das Auftreten ungekuppelter Gallensauren in menschlicher Galle. Ztschr. f. physiol. Chem., 1932, 208, 182.
8. Windaus, A., and Bohne, A., Uber Hyo-glyko-desoxycholsaure und uber Hyo-desoxy-cholsaure. Liebig's Ann. der Chem., 1923, 433, 278.

9. Wieland, H., and Reverey, G., Untersuchungen uber die Gallensauren. XXI. Mitteiling. Zur Kenntnis der menschlichen Galle. 1. Ztschr. f. physiol. Chem., 1924, 140, 186.

10. Wieland, H., and Seibert, W., Untersuchungen uber die Gallensauren. LVII. Mitteilung. Uber die Trennung der Inhaltsstoffe der Rindergalle. Ztschr. f. physiol. Chem., 1939, 262, 1.

11. Irvin, J. L., Johnston, C. G., and Anderson, C. E., Effect of oral administration of desiccated hog bile on the bile acid composition of human and canine fistula bile. Am. J. Physiol., 1939, 126, 544.

12. Irvin, J. L., Johnston, C. G., and Sharp, E. A., The enterohepatic circulation of foreign bile acids: the circulation of cholates in hogs with biliary fistulae. Am. J. Physiol., 1946, 146, 293.

13. Irvin, J. L., Johnston, C. G., and Kopala, J., A photometric method for the determination of cholates in bile and blood. J. Biol. Chem., 1944, 153, 439.

14. (a) Kaziro, K., and Shimada, T., Uber eine neue Farbreaktion der Desoxycholsäure. Ztschr. f. physiol. Chem., 1938, 254, 57.

(b) Shimada, T., Uber eine Bestimmungsmethode der Desoxycholsäure. J. Biochem. (Japan), 1939, 29, 41.

(c) Shimada, T., Weitere Studien uber die Benzaldehyde-Reaktion der Desoxycholsäure. J. Biochem. (Japan), 1938, 28, 169.

15. Windaus, A., Uber die Konstitution der Hyo-desoxycholsaure. Liebig's Ann. der Chem., 1926, 447, 233.

16. Schmidt, C. L. A., and Dart, A. E., The estimation of bile acids in bile. J. Biol. Chem., 1921, 45, 415.

17. Richey, B. R., A method for regulating pressure in the common duct following choledochostomy. Am. J. Surg., 1940, 48, 609.

18. Walters, W., Greene, C. H., and Fredrickson, C. H., The composition of the bile following the relief of biliary obstruction. Ann. Surg., 1930, 91, 686.

19. Greene, C. H., Walters, W., and Fredrickson, C. H., The composition of the bile following the relief of of biliary obstruction. J. Clin. Invest., 1930-31, 9, 295.

20. Breusch, F., and Johnston, C. G., Zum Verschwinden und Wiedererscheinen der Gallensäuren in der Galle bei vorubergehendem Choledochusverschluss. Klin. Wchnschr., 1934, 13, 1856.

21. Wieland, H., and Jacobi, R., Untersuchungen uber die Gallensauren. XXIII. Mitteilung. Weiteres uber die Zusammensetzung der Galle des Menschen und des Rindes. Zur Konstitution der Anthropodesoxy-cholsaure. Ztschr. f. physiol. Chem., 1925, 148, 232.

22. Colp, R., and Doubilet, H., Differential analysis of bile acids in human gallbladder bile. Arch. Surg., 1936, 33, 913. 
23. (a) Josephson, B., The circulation of bile acids in connection with their production, conjugation, and excretion. Physiol. Rev., 1941, 21, 463.

(b) Josephson, B., and Larsson, H., Elimination of cholic acids. V. Quantity and course of the normal secretion and circulation in man. Acta med. Scandinav., 1941, 107, 584.
24. Whipple, G., and Smith, H. P., Bile salt metabolism. IV. How much bile salt circulates in the body? J. Biol. Chem., 1928, 80, 697.

25. Berman, A. L., Snapp, E., Ivy, A. C., and Atkinson, A. J., On the regulation or homeostasis of the cholic acid output in biliary-duodenal fistula in dogs. Am. J. Physiol., 1941, 131, 776. 